\title{
Silver/Chitosan Nanocomposites: Preparation and Characterization and Their Fungicidal Activity against Dairy Cattle Toxicosis Penicillium expansum
}

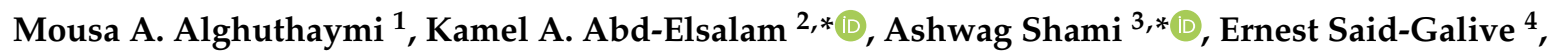 \\ Eleonora V. Shtykova ${ }^{5}$ and Alexander V. Naumkin ${ }^{4}(\mathbb{D}$ \\ 1 Biology Department, Science and Humanities College, Shaqra University, Alquwayiyah 11726, Saudi Arabia; \\ malghuthaymi@su.edu.sa \\ 2 Plant Pathology Research Institute, Agricultural Research Center (ARC), Giza 12619, Egypt \\ 3 Biology Department, College of Sciences, Princess Nourah bint Abdulrahman University, Riyadh 11617, \\ Saudi Arabia \\ 4 A.N. Nesmeyanov Institute of Organoelement compounds (INEOS) of Russian Academy of Sciences, \\ 119991 Moscow, Russia; ernest@ineos.ac.ru (E.S.-G.); naumkin@ineos.ac.ru (A.V.N.) \\ 5 V. Shubnikov Institute of Crystallography of Federal Scientific Research Centre "Crystallography and \\ Photonics" of Russian Academy of Sciences, 119333 Moscow, Russia; shtykova@ns.crys.ras.ru \\ * Correspondence: kamelabdelsalam@gmail.com (K.A.A.-E.); AYShami@pnu.edu.sa (A.S.); \\ Tel.: +20-10-910-49161 (K.A.A.-E.); +966-11-823-3175 (A.S.)
}

Received: 9 March 2020; Accepted: 17 April 2020; Published: 19 April 2020

Abstract: This work aimed to evaluate the fungicide activity of chitosan-silver nanocomposites (Ag-Chit-NCs) against Penicillium expansum from feed samples. The physicochemical properties of nanocomposites were characterized by X-ray fluorescence analysis (XRF), small-angle X-ray scattering (SAXS), X-ray photoelectron spectroscopy (XPS), and transmission electron microscopy (TEM). The morphological integrity of the nanohybrid was confirmed by electron transmission. By the data of RFA (X-ray fluorescent analysis), the contents of Ag in Ag-chitosan composite were $5.9 \mathrm{w} / \mathrm{w} \%$. The size distribution of the Ag nanoparticles incorporated in the chitosan matrix was investigated by SAXS. The main part of the size heterogeneity distribution in the chitosan matrix corresponds to the portion of small particles (3-4 nm). TEM analysis revealed a spherical morphology in the form of non-agglomerated caps, and $72 \%$ of the nanoparticles measured up to $4 \mathrm{~nm}$. The minimum inhibitory concentration of NCs was evaluated in petri dishes. Three different concentrations were tested for antifungal activity against the mycotoxigenic $P$. expansum strain. Changes in the mycelium structure of $P$. expansum fungi by scanning electron microscopy (SEM) were observed to obtain information about the mode of action of Ag-Chit-NCs. It was shown that NC-Chit-NCs with sizes in the range from 4 to $10 \mathrm{~nm}$ have internalized sizes in cells, form agglomerates in the cytoplasm, and bind to cell organelles. Besides, their ability to influence protein and DNA fragmentation was examined in P. expansum. SDS-PAGE explains the apparent cellular protein response to the presence of various Ag-Chit-NCs. The intensity of P. expansum hyphal cell protein lines treated with Ag-Chit-NCs was very thin, indicating that high molecular weight proteins are largely prevented from entering the electrophoretic gel, which reflects cellular protein modification and possible damage caused by the binding of several protein fragments to Ag-Chit-NCs. The current results indicate that Ag-Chit-NCs $<10 \mathrm{~nm}$ in size have significant antifungal activity against P. expansum, the causative agent of blue mold-contaminated dairy cattle feed.

Keywords: citrinin; nanocomposites; mycotoxins; patulin; P. expansum 


\section{Introduction}

Post-harvest fungal pathogens, such as Penicillium expansum (Link) Thom., are one of the most well-known microbes in the ecosystem and one of the first fungal species identified in the Penicillium genus [1]. P. expansum is found to manifest in various types of food and taken and adopted in different climate zones [2]. Mycotoxins, which are produced by various Penicillium species, such as $P$. roqueforti, $P$. paneum, and $P$. expansum, have been reported in silage and have caused animal health problems depending on the year of sampling and forage species [3]. Two types of fungi can produce roxfortin C (ROC), and P. roqueforti also produce PR toxin and mycophenolic acid (MPA), whereas P. paneum and P. expansum produce patulin [2,3]. P. expansum usually occurs in soil and is associated with some moldy fruits and vegetables, especially rotten apples and figs. It is the main source of citrinin and patulin in natural products [4]. P. expansum has also been isolated in fish feed, and the use of vegetable waste as a nutrient may be the reason for the existence of this species in processed fish feed [5]. Food and feed contamination with patulin and citrinin is quite low, but patulin occurs in apple juice, apples, and pears that are exposed to brown rot, as well as in grapes, flowers, and animal feed during storage [4]. Mycotoxins, which are produced by certain Pencillium species, for example, patulin, PR toxin, roxfortin, and mycophenol, are known for their high ability to cause mycotoxicosis in animals. Synthetic chemical antimicrobials are broadly utilized in conventional agriculture to manage plant diseases. However, environmental dangers caused by the immoderate use of chemical antimicrobial agents pose health problems as the current society is becoming more health conscious. Therefore, agricultural researchers are developing green and eco-friendly techniques to control plant diseases [6]. Nanomaterials have received a unique interest because of their exciting physical and chemical properties. Nanotechnology has benefited the area of food protection due to the construction of new antifungal agents, particularly for the reduction of chemicals fungicides, and similarly, it has been used to absorb mycotoxins [7,8]. Colloid solutions from silver nanoparticles (Ag NPs) containing concentrations up to $35 \mathrm{ppm}$ have been found to have inhibitory effects on three fungal genera, including Aspergillus, Penicillium, and Trichoderma [9]. The minimum growth inhibition concentration of silver nanocomposite, silver nitrate, and silver zeolite for Aspergillus niger was determined by Egger et al. (2009) [10]. Ag NPs have been shown to have strong antifungal properties. The effects of Ag NPs on plant pathogenic spores of Fusarium culmorum have been described by Kasprowicz et al. (2010) [11,12]. They are safe inorganic antimicrobials and can kill more than 650 species of microorganisms [13]. Ag NPs are one of the most systematically studied nanomaterials and have gained popularity because of their biocidal activity against fungi $[14,15]$. Chitosan silver nanoparticles have been examined for the control of fungal pathogens that were transmitted from seeds to beans. Significant antifungal activity against Aspergillus flavus, R. solani, and Alternaria alterneta was alternatively observed [16]. The antifungal properties of silver-chitosan nanoparticles functioned with 4(E)-2-(3-hydroxynaphthalin-2-yl)diazen-1-yl) and benzoic acid were evaluated for the control of Aspergillus flavus and A. terreus. An inhibition of fungal growth was shown between 20.2 and $27.0 \mathrm{~mm}$ [17]. The chitosan antifungal activity in combination with silver to combat Colletotrichum gloeosporioides was evaluated using mangoes (Mangifera indica). The two concentrations showed a reduction in anthracnose symptoms by $45.7 \%$ and $71.3 \%$, respectively [18]. The antifungal activity of silver ions against two strains of pathogenic fungi, namely Aspergillus avus and Penicillium vulpinum, and the effectiveness of silver ions in inhibiting the production of AFB1 and patulin by two toxigenic fungal strains was tested in vitro. Additionally, silver ions have antifungal activity in the production of AFB1 and patulin [19]. There has been no past report on the utilization of Ag-Chit-NCs against toxic strains from Penicillium ascomycetous fungi. Ag NPs are extremely powerful against phytopathogens with low poisonous quality and lead to a broad range of applicability in pesticidal activity. It is proficiently utilized for site-targeted delivery of significant agrochemical substances $[6,18]$. Likewise, silver NPs embedded in a polymer network (Ag NP/polymer nanocomposites) are brilliant competitors as antimicrobial substances and have been used in food packaging to improve the timeframe of realistic usability of food, and the management toxigenic fungi 
and plant pathogens $[6,7,20,21]$. The main aim of the current research was to synthesize and characterize chitosan-silver nanocomposite using a supercritical carbon dioxide medium. The physicochemical properties of the produced nanocomposites were characterized by $\mathrm{X}$-ray fluorescence analysis (XRF), small-angle X-ray scattering (SAXS), X-ray photoelectron spectroscopy (XPS), and transmission electron microscopy (TEM). The fungicidal impact of Ag-Chit-NCs was assessed against Penicillium expansum strains. The protein and DNA degradations were measured utilizing acrylamide and agarose gel electrophoresis, respectively.

\section{Materials and Methods}

\subsection{Synthesis and Characterization of Ag NPs-Chitosan Nanocomposites}

High molar mass chitosan (HMWC) ("Acros Organics"), a powder fraction with a size of $40 \mu \mathrm{m}$ and less with MM of $600-800 \mathrm{KDa}$ and $\mathrm{DD}>75 \%$, was used as a matrix. The organometalic complex (1,5-cyclooctadiene)(1,1,1,5,5,5-hexafluoroacetylacetonato)silver(I) CODAg(hfacac), a greyish crystalline compound, m.p. $122-124{ }^{\circ} \mathrm{C}$, solubility in $\mathrm{SC} \mathrm{CO}_{2} \sim 10^{-5} \mathrm{~mol} / \mathrm{L}$ at $14 \mathrm{MPa}$, and $70{ }^{\circ} \mathrm{C}$ (according to our data), was used as a metal precursor for synthesis in $\mathrm{SC} \mathrm{CO}_{2}$ medium. The complex was purchased from Aldrich and used without additional purification. Carbon dioxide with a purity of 99.997 vol. \% and hydrogen of high purity $\left(\mathrm{H}_{2}\right.$ volume fraction not less $\left.99.999 \%\right)$ were purchased from Moscow Plant of pure gases "Linde gas". Acetone was distilled before use.

\subsection{Experimental Procedure}

The synthetic fluid technology for producing metal nanocomposites includes 4 stages: (1) chitosan drying in vacuum at the temperature of $373 \mathrm{~K}$; (2) impregnation of chitosan with the complex CODAg(hfacac) in $\mathrm{SC} \mathrm{CO}_{2}$ solution $(353 \mathrm{~K}, 20 \mathrm{MPa}, 7 \mathrm{~h})$, decompression; (3) purge of the reactor with hydrogen flow and the complex reduction in $\mathrm{H}_{2}$ atmosphere $(1.2 \mathrm{MPa}$ at the temperature of $353 \mathrm{~K}, 7 \mathrm{~h}$ ); and (4) washing with ethanol and acetone, and vacuum drying the Ag-chitosan NC at a temperature of $333 \mathrm{~K}$. After the first stage, chitosan lost water ( $9 \mathrm{w} / \mathrm{w} \% \%$ by TGA data). The second stage was carried out with $4.24 \mathrm{~g}(0.026 \mathrm{M})$ of chitosan and $1.059 \mathrm{~g}\left(2.5 \times 10^{-3} \mathrm{M}\right)$ of a silver complex $(25 \%$ from chitosan weight). The calculated ratio was one silver atom per 10.4 chitosan units. Chitosan, the silver complex, and stir bar were loaded into the reactor on its bottom. The reactor volume was $25 \mathrm{~cm}^{3}$. The impregnated polymer after the reduction stage was washed with ethanol and acetone to remove the residual unreduced complex and degradation products. Impregnation and reduction were carried out according to the procedure described elsewhere [22].

\subsection{X-Ray Fluorescence Analysis (XRF)}

Metal content was determined using XRF on a "VRA 30" X-ray fluorescent analyzer (Leipzig, Germany) from the line of the $\mathrm{AgK} \alpha$ spectrum of X-ray fluorescence (XF). To excite $\mathrm{XF}$, an X-ray tube with a Mo anode was used in the $50 \mathrm{kV}, 20 \mu \mathrm{A}$ regime. The powdered chitosan samples containing metal nanoparticles were analyzed as pressed pills. The reference sample for spectrometer calibration was made from a polystyrene and metal salt fine mix, containing $n \%$ of metal, with a layer of reference sample with a mass of $1.23 \mathrm{mg}$. The Ag K $\alpha$ peak height was created by the metal with a mass of $1.23 \times 0 . n$ $=$ mass of metal $(\mathrm{mg})$. The mass (and thus the concentration) of metal in the experimental sample was determined by comparing the peak height of the composite with that of the reference sample.

\subsection{Small-Angle Spread (SAXS)}

SAXS measurements were carried out with an AMUR-K diffractometer (designed by the Crystallography Institute of the Russian Academy of Sciences) at a wavelength of $\lambda=0.1542 \mathrm{~nm}$ with Kratky geometry (infinitely long slit). The heterogeneity of the size distribution was shown in the sample and their $\mathrm{Cu}$ nanoparticles were calculated using an indirect GNOM transformation 
program [23]. More detailed information about the experiments and calculations was explained earlier by Said-Galiev et al. (2011) [24].

\subsection{X-Ray Photoelectron Spectroscopy (XPS)}

The X-ray photoelectron spectrum was obtained with an Ultra DLD Axis spectrometer (Kratos, UK) using $\mathrm{Al} \mathrm{K \alpha}(1486.6 \mathrm{eV})$ monochromathic radiation with an operating power of $150 \mathrm{~W}$ on the $\mathrm{X}$-ray tube. High-resolution studies and corresponding to core spectrums were recorded at energies of 160 and $40 \mathrm{eV}$ and with step sizes of 1 and $0.1 \mathrm{eV}$, respectively. The sample area of $300 \mu \mathrm{m} \times$ $700 \mu \mathrm{m}$ contributed to the spectrum. The reference pressure in the analytical UHV chamber of the spectrometer during the measurement did not exceed $10^{-8}$ Torr. The spectrometer energy scale was calibrated to provide the following reference sample values (i.e., metal surfaces freshly cleaned

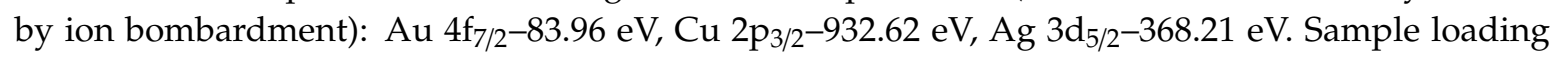
was improved by reference to the $\mathrm{C}-\mathrm{C} / \mathrm{C}-\mathrm{H}$ peak developed in the $\mathrm{C} 1 \mathrm{~s}$ spectrum $(284.8 \mathrm{eV})$. After cost abstraction, Shirley's high-resolution background with inelastic losses was reduced from the high-resolution spectrum. The Cu LMM and Zn LMM Auger spectrum were corrected using a linear background. The chemical composition of the surface was calculated using the atomic sensitivity coefficient contained in the spectrometer software, which was corrected for the instrument transfer function of the instrument.

\subsection{Transmission Electron Microscope (TEM)}

Powdered samples were ground in an agate mortar and then placed on a film-coated 200-mesh copper specimen grid. TEM micrographs were performed on Carl Zeiss Leo 912 AB OMEGA electron microscope at an accelerating voltage of $80 \mathrm{kV}$.

\subsection{Pencillium Identification}

Colony appearance, exudate formation, pigmentation, and re-staining were evaluated and the colony diameter measured and recorded after one week of growth at $25^{\circ} \mathrm{C}$. Five plates were inoculated at $25{ }^{\circ} \mathrm{C}$, with the microscopic slides made from 7-day PDA culture. Conidia morphology, type of conidiophores, color, and phialid shapes were evaluated, and conidia were measured with a Leica microscope, which was taken with a Leica DC 300 digital camera and Leica IM 1000 software equipped. Morphological identification of each isolate was carried out according to the method described by Visagie et al. (2014) [25].

\subsection{Patulin- and Citrinin-Producing Ability}

Seventeen Penicillium isolates collected from feed samples were grown in SKMY liquid media (200 g sucrose, $0.5 \mathrm{~g}$ magnesium sulfate, $3 \mathrm{~g}$ potassium nitrate, $7 \mathrm{~g}$ yeast, and $1000 \mathrm{~mL}$ distilled water extract) for 10 days at $25 \pm 2{ }^{\circ} \mathrm{C}$ After the incubation period, the contents of all flasks were blended on high speed for 2-3 min and mixed with $5 \mathrm{~g}$ of sodium chloride and then filtered on glass filter paper. Then, $100 \mathrm{~mL}$ of the fungus filtrate was centrifuged at $3500 \mathrm{~g}$ at $4{ }^{\circ} \mathrm{C}$ for $10 \mathrm{~min}$. The top layer was removed, and the sample subsequently diluted 20 times $(v / v)$ with deionized water. The suspension was filtered (Millipore, $0.45 \mu \mathrm{m}$ ) and the filtrate was centrifuged for $15 \mathrm{~min}$ at $15^{\circ} \mathrm{C}$ at $2700 \times g$ and the top phase was removed and a water-methanol layer $(100 \mu \mathrm{L})$ was added to $0.01 \mathrm{M}$ phosphate-buffered saline (PBS) $(900 \mu \mathrm{L}$; dilution 1:10). Patulin and citrinin were assayed in $100 \mu \mathrm{L}$ of the prepared solution.

Broth filtrate for the cultivation of the most commonly isolated Pencillium species, which was taken from various feed samples, was analyzed for poisons from patulin and citrinin (see the chemical formula in Figure 1. The mycotoxin productivity from 17 penicillium isolates representing 5 species was tested by HPLC (PerkinElmer ${ }^{\circledR}$ Brownlee ${ }^{\mathrm{TM}}$ (Waltham, MA 02451, USA) validated C18, $250 \mathrm{~mm}$, equipped with a UV detector. The total separation time was about $25 \mathrm{~min}$ with a flow rate of $1 \mathrm{~mL} / \mathrm{min}$ ). The isolates were cultured aseptically in triplicate in a $100-\mathrm{mL}$ flask of malt extract broth and incubated for 10 days at $27 \pm 2{ }^{\circ} \mathrm{C}$. The cultures were mixed for $2 \mathrm{~min}$ using high-speed homogenizers and filtered 
using glass filter paper. Patulin was extracted from homogenized filtrate using acetonitrile:water solution (5:95 v:v). The solvent was then evaporated in a vacuum at $35^{\circ} \mathrm{C}$. Residues containing dry patulin were dissolved in $1 \mathrm{~mL}$ of acetonitrile:water (5:95 $\mathrm{v}: \mathrm{v})$. The extract was then passed through a $0.45-\mu \mathrm{m}$ microfilter before HPLC analysis. The method described by Christian (1990) [26] was used to determine patulin. Citrinin was extracted from the homogenized filtrate using dichloromethane with the addition of phosphoric acid and the extract was then purified in a polyamide column. HPLC analysis of citrinin employed the method described by Franco et al. (1996) [27].

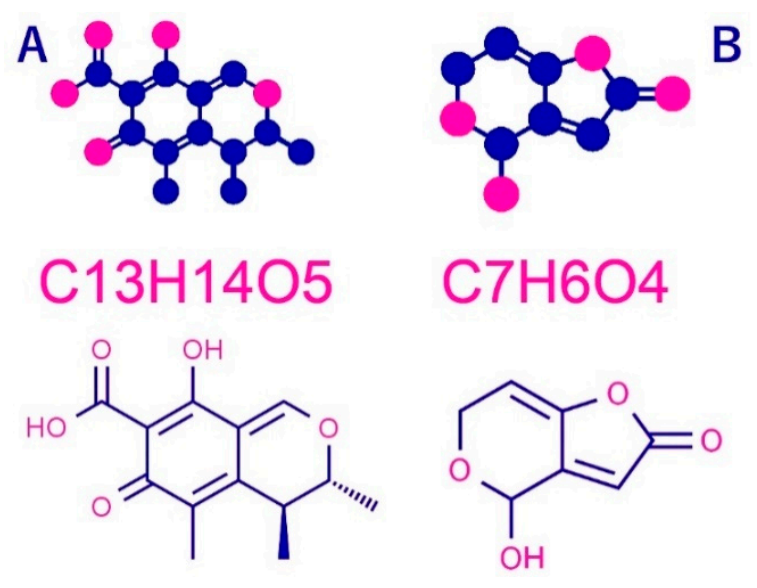

Figure 1. Structural formula of patulin and citrinin (A) Patulin, (2,4-dihydroxy-2H-pyran-3 (6H) ylidene) acetic acid, (B) Citrinin, acid 3,4-lactone, (3R, 4S)-7-(Dihydroxymethylene))-3,4,5trimethyl-3H-isochromic-6,8 $(4 \mathrm{H}, 7 \mathrm{H})$-dione. Red dot $(\mathrm{H})$ Blue $\operatorname{dot}(\mathrm{C})$. Data available online from: http://www.chemspider.com.

\subsection{Screening for Antifungal Activity}

To investigate the antifungal effects of Ag-Chit-NCs on P. expansum isolates, three chitosan NCs suspension concentrations $\left(0.30,0.60\right.$, and $\left.0.100 \mathrm{mg} \cdot \mathrm{mL}^{-1}\right)$ were prepared. The antifungal activity of Ag-Chit-NCs was detected by calculating the decrease in fungal growth of two pathogenic species using agar-well diffusion tests (Perez et al., 1990). A $5 \mathrm{~mm}$ diameter well was made in a Petri dish, $30 \mu \mathrm{m}$. Each concentration of Ag-Chit-NCs was added to the agar. The plates were inoculated with fungal discs from P. expansum isolates and incubated at $28{ }^{\circ} \mathrm{C}$ for 10 days. Positive control media (without chitosan) were inoculated in the same way. The rate of growth inhibition was measured and calculated using the following formula [28]:

Growth Inhibition $(\%)=(C-P) / C \times 100$, where $C$ is the diameter of mat growth in the control plate and $P$ is the diameter of micelle growth in the processed plate. Five treatment repetitions were used, and the present assay was repeated three times.

\subsection{Protein Degradation Test}

Protein damage in the fungal cells of P. expansum incubated with Ag-Chit-NCs was examined using SDS-PAGE, which was carried out according to the protocol published by Laemmli (1970) [29]. SDS-PAGE was performed using a $5-10 \%$ gradient of polyacrylamide gels containing $0.1 \%$ SDS. Proteins were analyzed in $1.5 \mathrm{~mm}$ and $15 \mathrm{~cm}$ gels that worked in double vertical plates (Hoefer Scientific Instruments, San Francisco, CA, USA). Then, $25 \mu \mathrm{L}$ of protein extract from each sample was put into a polyacrylamide gel. Protein was electrophoresed at a constant electric current of $30 \mathrm{~mA}$ through stacking gel, and at $90 \mathrm{~mA}$ through separating gel at room temperature, and the gel was stained with silver staining [30]. The standard molecular weight used for gel analysis was the Sigma protein marker, which ranged between 66,000, 45,000, and 22,000 kDa. 


\subsection{Binding/Degradation of Genomic Fungal DNA}

The fungal mats of P. expansum were prepared in $20 \mathrm{~mL}$ of liquid media $\left(24 \mathrm{~g} \cdot \mathrm{L}^{-1}\right.$ potato dextrose broth (PDB, Difco Laboratories)). Mycelium was harvested by filtration through mesh sieves $(40 \mu \mathrm{m})$, washed with sterile water, and deposited onto Whatman paper to eliminate excess water. Mycelium was ground to a fine powder in liquid nitrogen using a mortar and pestle. Fungal DNA was extracted by the method of Moslem et al. (2010) [31]. To check the DNA quality, $10 \mu 1$ of P. expansum DNA were treated with Ag-Chit-NCs $\left(40 \mu \mathrm{g} \cdot \mathrm{mL}^{-1}\right)$ for $2 \mathrm{~h}$ at $37^{\circ} \mathrm{C}$. The products resulting from the interactions of the NPs with DNA were separated by $1.5 \%(w / v)$ agarose gel containing $0.05 \mu \mathrm{g} \cdot \mathrm{mL}^{-1}$ ethidium bromide. Gel Documentation and Analysis Systems, Uvitec (Cambridge, UK) were used to capture the image.

\subsection{Scanning Electron Microscopy (SEM)}

Penicillium biomass obtained from fungal cultures grown on PDB treated with and without Ag-Chit-NCs for one week was used for a scanning electron microscopy (SEM) test to demonstrate the probable modes of action. About $5 \times 10 \mathrm{~mm}$ segments were cut from a culture grown on PDA plates and immediately inserted in bottles containing 3\% glutaraldehyde in $0.05 \mathrm{M}$ phosphate buffer (pH 6.8) at $4{ }^{\circ} \mathrm{C}$. Samples were held in this solution for $48 \mathrm{~h}$ to be repaired and then washed three times for $20 \mathrm{~min}$ each with distilled water. Samples were then dehydrated for $20 \mathrm{~min}$ in the ethanol series dilution $(30 \%, 50 \%, 70 \%$, and $95 \%)$ at each dilution with ethanol and finally in absolute ethanol for $45 \mathrm{~min}$. The sample was then critically dried in liquid carbon dioxide. Penicillium fragment segments were placed in a desiccator until further use. After drying, the prepared samples were installed using standard double-sided adhesive on standard $\frac{1}{2}$-inch SEM nozzles and with gold-palladium galvanoplastics ( $60 \mathrm{~s}, 1.8 \mathrm{~mA}, 2.4 \mathrm{kV}$ ) in the coated Poutron SEM Coat coating system. All samples were examined in JEOL JXA-480 SEM (JEOL, Tokyo, Japan), which operated at $15 \mathrm{kV}$ at 6000 -fold magnification. SEM works in the SEM department of the National Research Center's Central Unit for Scientific Analysis and Services in Giza, Egypt. JEOL JXA-480 SEM.

\subsection{Statistical Analyses}

The experimental design was a randomized complete block, with five replications in the greenhouse assay and five replications in the laboratory test. Data were subjected to analysis of variance (ANOVA). Least significant difference (LSD) was used to compare concentration means within genotypes. ANOVA was performed with MSTAT-C statistical package, Version 2.0.0.

\section{Results}

\subsection{Physico-Chemical Characterization of Silver/Chitosan Nanocomposites}

From the data of RFA (X-ray fluorescent analysis), the contents of Ag in Ag-chitosan composite were $5.9 w . \%$. The size distribution of Ag nanoparticles incorporated in the chitosan matrix was investigated by SAXS. The volume size distribution functions of scattering heterogeneities in the initial high molecular mass chitosan after exposition in $\mathrm{SC} \mathrm{CO}_{2}(1)$ and of the Ag nanoparticles impregnated with COD Ag[hfacac] in the chitosan matrix (2) were calculated from the scattering data using GNOM program. The results of the size distribution analysis are given in Figure 2

As shown in Figure 2, the volume size distributions of both scattering inhomogeneities in the initial chitosan matrix (Figure 2, curve 1) and Ag nanoparticles formed in it (Figure 2, curve 2) demonstrate a bimodal character: Two fractions of small and large scattering inhomogeneities were observed (Table 1). However, the initial chitosan matrix is characterized by a much wider size distribution containing inhomogeneities with sizes up to $60 \mathrm{~nm}$. Interesting, after the reduction, Ag nanoparticles form the main fraction with the same sizes of about $3-4 \mathrm{~nm}$ as a fraction of small inhomogeneities observed in the initial chitosan. Thus, one can conclude that the metal nanoparticles formed and were located in the small pores (3-4 nm of size) of the polymer matrix. They also formed associates with sizes up to $30 \mathrm{~nm}$ but not so large as the size of the largest inhomogeneities in the initial matrix. 


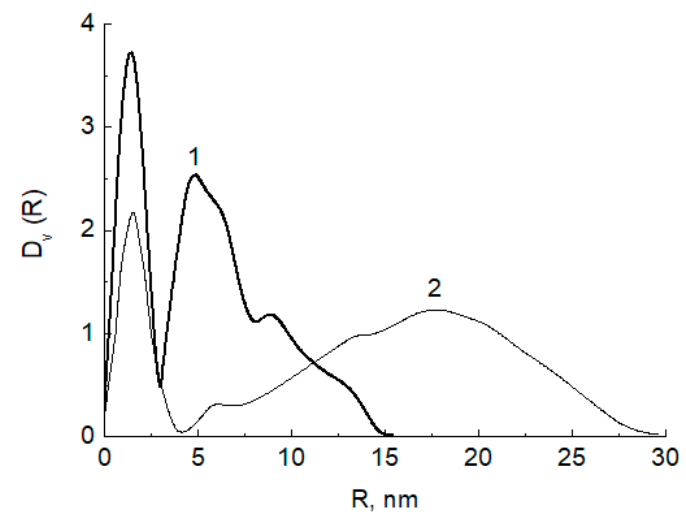

Figure 2. 1-volume size distribution function of the scattering heterogeneities in initial high molecular weight chitosan after exposition in $\mathrm{SC} \mathrm{CO}_{2}\left(25 \mathrm{MPa}, 80^{\circ} \mathrm{C}\right) ; 2$ - size distribution function $\mathrm{D}_{\mathrm{v}}(\mathrm{R})$ of the high molecular weight chitosan sample after impregnation with Ag-complex and reduction with hydrogen (1.15 $\left.\mathrm{MPa}, 65^{\circ} \mathrm{C}\right)$. Sample 1: chitosan (HMWC), Sample 2: chitosan matrix.

Table 1. Elemental composition of the samples determined from the survey spectra.

\begin{tabular}{ccccccccc}
\hline Sample & $\mathbf{C}$ & $\mathbf{O}$ & $\mathbf{A g}$ & $\mathbf{S i}$ & $\mathbf{Z n}$ & $\mathbf{N}$ & $\mathbf{C l}$ & $\mathbf{F}$ \\
\hline 1 & 66.38 & 24.38 & 1.25 & 4.06 & 0.22 & 3.70 & - & - \\
\hline 2 & 59.43 & 27.72 & - & 3.71 & 0.51 & 4.93 & 0.14 & 3.56 \\
\hline \multicolumn{7}{c}{ Sample 1: chitosan (HMWC), Sample 2: chitosan matrix. }
\end{tabular}

Figure 3 shows the $C$ 1s spectra of samples 1 and 2 . After the deposition of silver, an increase in the relative concentrations of the $\mathrm{C}-\mathrm{C} / \mathrm{C}-\mathrm{H}$ and $\mathrm{CF}_{\mathrm{x}}$ groups in the $\mathrm{C} 1$ s spectrum was observed. The $\mathrm{O}$ 1s spectra of samples 1 and 2 are similar.

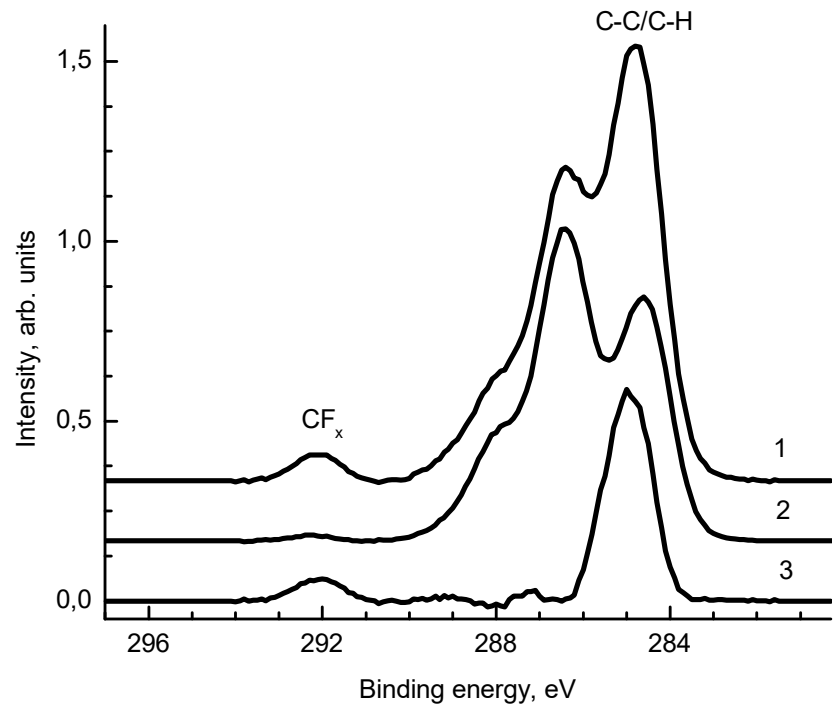

Figure 3. The $\mathrm{C} 1$ s spectra of samples 1 and 2 and their difference spectrum 3.

Figure 4 presents the Ag 3d photoelectron and Ag MNN Auger spectra. To identify the chemical state of silver atoms, both the binding energy (BE) and modified Auger parameter were used [32]. A compilation of the literature data for Ag-Ag and Ag-O bonds [32-43]. The binding energies of the $\mathrm{Ag} 3 \mathrm{~d}_{5 / 2}$ peak for $\mathrm{Ag}, \mathrm{Ag}_{2} \mathrm{O}$, and $\mathrm{AgO}$ according to the NIST XPS database [42] are in the ranges 367.9-368.4, 367.7-368.4, and 367.3-368.1 eV, respectively. Taking into account that the most accurate binding energy of the $\mathrm{Ag} 3 \mathrm{~d}_{5 / 2}$ peak for solid silver is $368.327 \mathrm{eV}$, the corresponding kinetic energy for the Ag M4N45N45 peak is $357.855 \mathrm{eV}$, and the Auger parameter is $726.182 \mathrm{eV}$ [41,44], one can conclude that the chemical state of silver in sample 1 corresponds to the Ag0 state. 

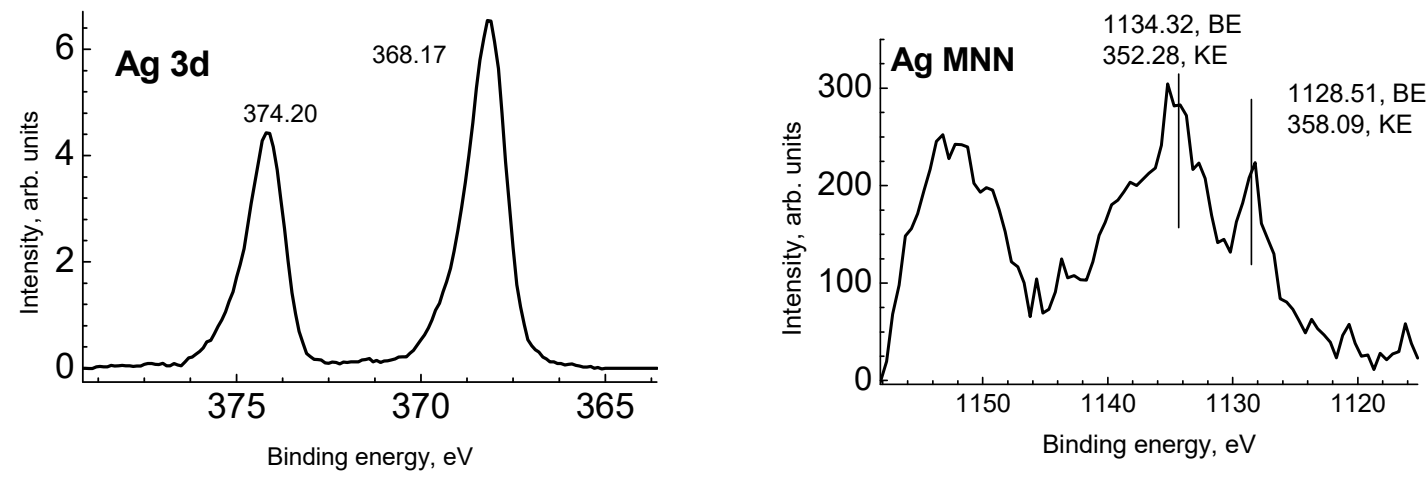

Figure 4. The Ag 3d and Ag MNN spectra of sample 1.

The TEM results showed the formation of spherical silver nanoparticles "dark field" with a size ranging from 4 to $10 \mathrm{~nm}$ was recorded in the next $92 \%$ of the total percentage, homogeneously distributed in the chitosan matrix. The TEM photos do not show aggregate between the Ag NPs. This is mainly due to the carboxylic coordination on the silver surface, which can effectively prevent aggregation and fusion between nanoparticles. The particles are small and there are some large clusters on the chitosan powder surface (Figure 5).

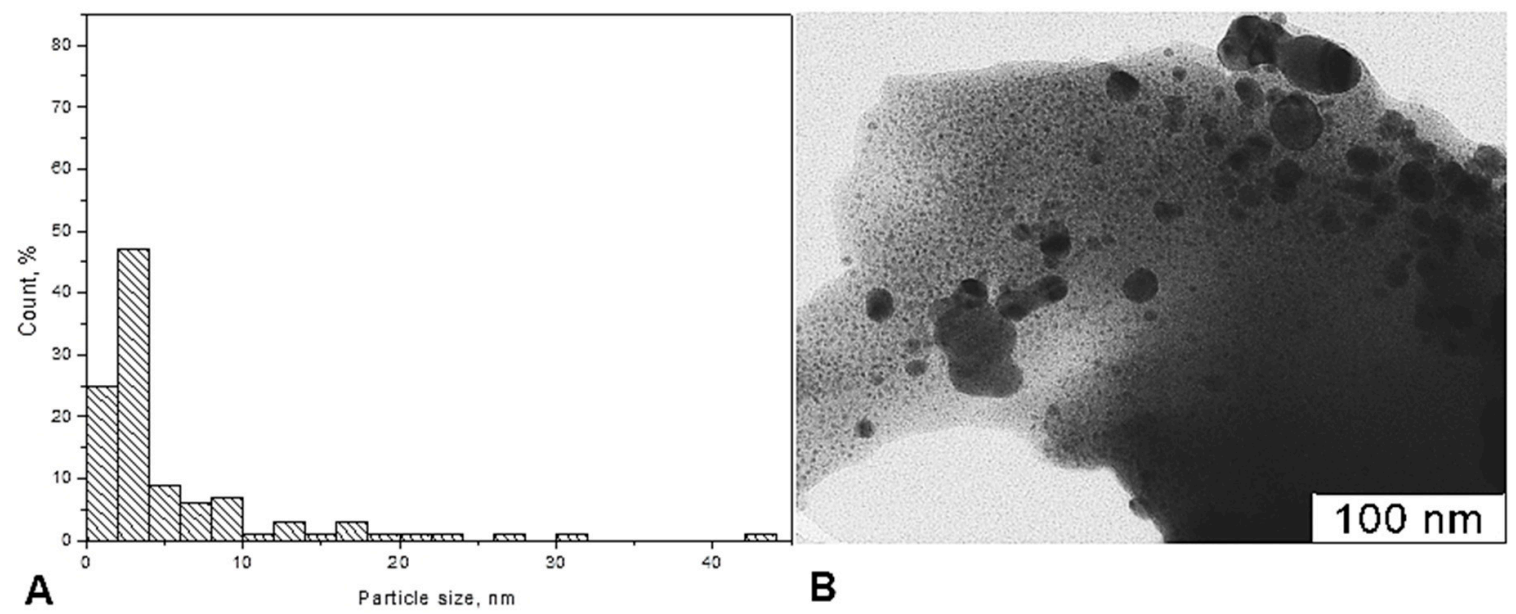

Figure 5. (A) Particle size analyser data, (B) Transmission electron microscopic image of Ag NPs Chitosan nanocomposites.

\subsection{Analysis of Toxins for Patulin and Citrinin}

The quantitative results of the Penicillium spp toxicity test are shown in Table 2. In total, 3 of the 17 tested isolates produced both patulin and citrinin toxins. The productive P. paneum (isolate 2) produced 91.10 parts per billion (ppb), and P. expansum isolate produced 83.14 and $72.20 \mathrm{ppb}$ patulin and citrinin, respectively. P. citrinum isolate 3 produced $197.20 \mathrm{ppb}$ of citrinin (Table 3 and Figure 6). Isolates vary in the type and concentration of toxins produced. It is noteworthy that most of the P. expansum isolates tested $(100 \%)$ were bitoxic (co-producers of patulin and citrinin), with very high patulin production. To evaluate the antifungal activity, three different fungal isolates varying significantly in mycotoxin-producing abilities were selected (highly producer (HP), intermediate producers (IP), and low producers (LP)). 
Table 2. Penicillium spp. isolates used in mycotoxins assay.

\begin{tabular}{ccccc}
\hline \multirow{2}{*}{ Isolate Code } & \multirow{2}{*}{ Pencillium Species } & \multirow{2}{*}{ Feed Source } & \multicolumn{2}{c}{ Mycotoxin Concentration (ppb) } \\
\cline { 4 - 5 } & & & Patulin & Citrinin \\
\hline 1. & Penicillium paneum & maize silages & 37.40 & ND \\
\hline 2. & Penicillium paneum & maize silages & 91.10 & ND \\
\hline 3. & Penicillium paneum & maize silages & 80.36 & ND \\
\hline 4. & Penicillium expansum & cottonseed meals & 0.00 & 40.19 \\
\hline 5. & Penicillium expansum & maize silages & 13.90 & 11.70 \\
\hline 6. & Penicillium expansum & maize silages & 44.50 & 50.63 \\
\hline 7. & Penicillium expansum & maize silages & 83.14 & 72.20 \\
\hline 8. & Penicillium citrinum & maize-Bran & ND & 120.0 \\
\hline 9. & Penicillium citrinum & dry natural forage & ND & 88.56 \\
\hline 10. & Penicillium citrinum & dry natural forage & ND & 197.20 \\
\hline 11. & Penicillium citrinum & sunflower oilcake & ND & 77.13 \\
\hline 12. & Penicillium citrinum & maize silages & ND & 0.0 \\
\hline 13. & Penicillium citrinum & dry natural forage & ND & 60.22 \\
\hline 14. & Penicillium griseofultum & dry natural forage & 67.50 & ND \\
\hline 15. & Penicillium verrucosum & maize silages & ND & 97.18 \\
\hline 16. & Penicillium verrucosum & maize silages & ND & 143.0 \\
\hline 17. & Penicillium verrucosum & maize silages & ND & 24.00 \\
\hline & &
\end{tabular}

$\mathrm{ND}$, not detected, ${ }^{*}$ highly producer isolate.

Table 3. Zone of inhibition of Ag-Chit-NCs against Penicillium expansum isolates, including three levels of mycotoxins, high producer (HP), intermediate producer (IP), and low producer (LP) collected from maize silage.

\begin{tabular}{ccccc}
\hline \multirow{2}{*}{ Concentrations $\left(\mathbf{m g} \cdot \mathbf{m L}^{-1}\right)$} & \multicolumn{4}{c}{ Penicillium expansum Strains } \\
\cline { 2 - 5 } & LP & IP & HP & Mean \\
\hline 0.30 & 3.16 & 3.48 & 2.50 & 3.16 \\
\hline 0.60 & 3.66 & 3.56 & 2.45 & 3.66 \\
\hline 0.90 & 3.79 & 3.82 & 2.39 & 3.79 \\
\hline Control & 0.00 & 0.00 & 0.00 & 0.00 \\
\hline LSD $(p<0.05)$ & 0.363 & 0.234 & 0.220 & - \\
\hline
\end{tabular}

Inhibition zone (cm) and each value is mean of five replications (three plates).

Patulin Citrinin

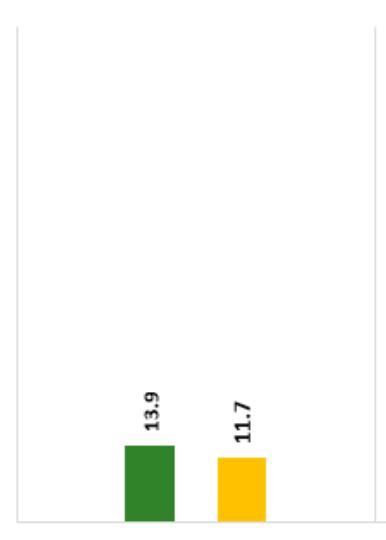

LP

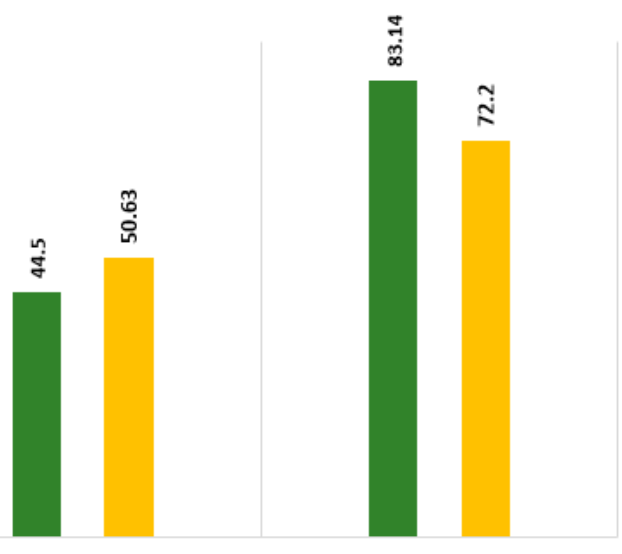

IP
HP

Figure 6. The quantitative results of patulin and citrinin assays of P. expansum isolates, including three levels of mycotoxins, high producer (HP), intermediate producer (IP), and low producer (LP). 


\subsection{Antifungal Activity}

The colloidal solutions of Ag-Chit-NCs at various concentrations $\left(0.30,0.60\right.$, and $\left.0.100 \mathrm{mg} \cdot \mathrm{mL}^{-1}\right)$ with particle sizes ranging from $4-10 \mathrm{~nm}$ were used to evaluate the inhibitory activity against dairy cattle toxicosis P. expansum through treatment duration. P. expansum LP and IP isolates were entirely inhibited at all tested concentrations of Ag-Chit-NCs of $0.30 \mathrm{mg} \cdot \mathrm{mL}^{-1}$ after 7 days of incubation. The developed nanocomposites showed a low inhibition zone with the efficient producer of high levels of patulin and citrinin (HP isolate). The control treatment did not enhance the antifungal activity (Table 3 and Figure 7). To our knowledge, the present study establishes the first application of Ag-Chit-NCs as an antifungal against P. expansum collected from feed samples.

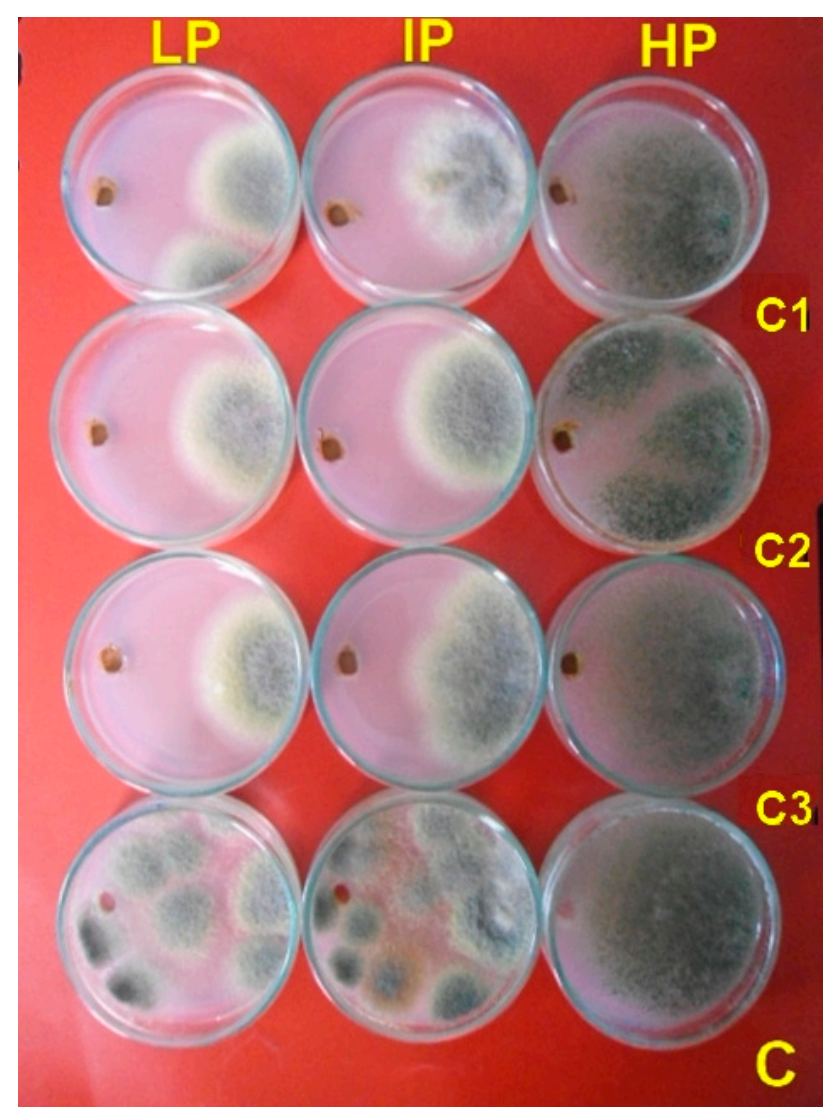

Figure 7. Antifungal activity for different concentration of Ag-Chit-NCs $(\mathrm{C} 1=0.30, \mathrm{C} 2=0.60$, and $\mathrm{C} 3=0.100 \mathrm{mg} \cdot \mathrm{mL}^{-1}$ ) against P. expansum isolated from feeds by the plate assay. All Petri dish treatments were incubated at $28^{\circ} \mathrm{C}$ for 10 days.

\subsection{Characterize Nanocomposites-Fungal Protein Interactions}

SDS-PAGE gel electrophoresis was performed to screen the modification of gene expression of P. expansum treated with various concentrations of Ag-Chit-NCs. Many protein bands were found in P. expansum, which were exposed and not exposed to Ag-Chit-NCs. The protein profile in the control group shows a clearer protein band. Specifically, there were three major bands in the protein maker, including 66, 45, and $22 \mathrm{kDa}$, respectively. Seven bands completely disappeared after treatment with $0.90 \mathrm{mg}$ of Ag-Chit NC, with molecular weights of 62, 60, 47, 38, 27, and $20 \mathrm{kDa}$. P. expansum secretes four different proteins, with molecular weights between 60, 47, 38, and $10 \mathrm{kDa}$ (Figure 8). P. expansum isolates under pressure with the presence of Ag-Chit-NCs in higher concentrations can reduce the production of some proteins. The amount of protein expression in each treatment varies with the control, exactly where the band intensity of each treatment was changed as compared with their control. Compared to untreated wells, seven bands were degraded in P. expansum isolates. 


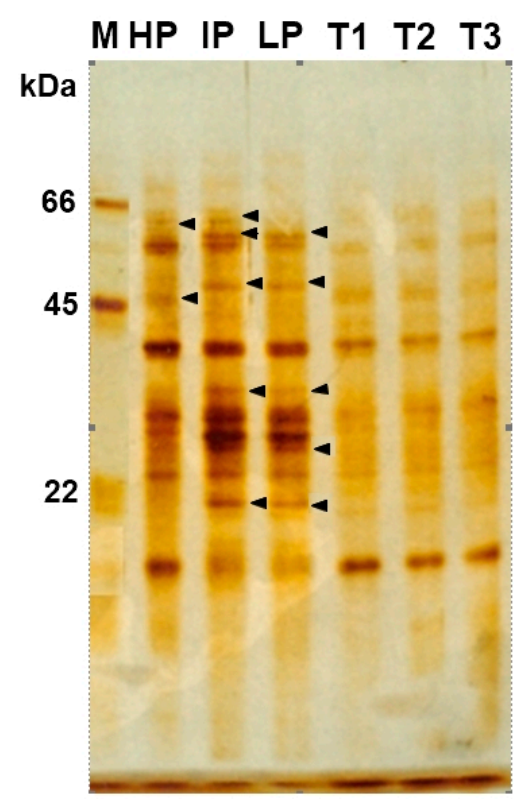

Figure 8. Protein expression profile of silver-stained SDS-PAGE from P. expansum mats at a high Ag-Chit-NCs concentration. Lane M contains a protein marker. Protein bands are shown in the black arrow (seven reduced band). The protein standards with molecular weights ranging from 66,45 , and $22 \mathrm{kDa}$ were used. P. expansum isolates, including three levels of mycotoxins, high producer (HP), intermediate producer (IP), and low producer (LP). The same isolates treated with Ag-Chit NCs as a fellow T1, T2, and T3, respectively.

\subsection{Analysis of the Binding/Degradation of Fungal Genomic DNA}

Agarose electrophoresis of genomic DNA from fungi exposed to Ag-Chit-NCs showed fragmented and smeared DNA compared to the controls. Control DNA shows the main band of intact/unaffected genomic DNA, where no significant damage occurred. In contrast, fungi treated with different concentrations of silver nanoparticles show induction depending on the termination of DNA strands, which are characterized by increased DNA fragmentation (Figure 9). In this study, the genotoxicity manifested by Ag-Chit-NCs was demonstrated by DNA fragmentation after treatment, especially at concentrations of 30 and $40 \mu \mathrm{g} \cdot \mathrm{mL}^{-1}$ with high concentrations of Ag-Chit-NCs.

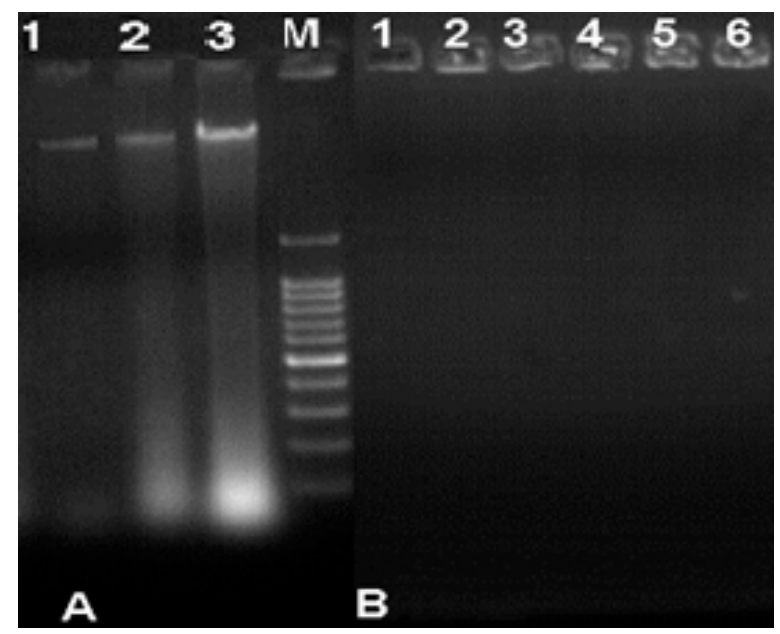

Figure 9. Agarose gel electrophoretic pattern of the fungal genomic DNA treated with $10 \mu \mathrm{L}$ Ag-Chit-NCs. A: Lanes 1-3: DNA for untreated P. expansum isolates, Lanes 1: P. expansum 1, Lane 2: P. expansum 2, Lane 3: P. expansum 3. B: Lanes 1-6: three P. expansum isolates DNA treated with Ag-Chit nanocomposites $\left(30\right.$, and $40 \mu \mathrm{g} \cdot \mathrm{mL}^{-1}$ ) showed total damage to fragmented DNA bands. 


\subsection{Fungal Morphology Observation}

P. expansum isolates grown on PDA plates showed the characteristic mycelial and conidiospores morphology, with lengthened, normal, and homogenous hyphae of a constant diameter with smooth external surfaces and rounded apices (Figure 10a,d). Healthy mycelia of the untreated (control) consisted of conidiophores formed of smooth stipes 200 to $500 \mu \mathrm{m}$ long and ending in typically triverticillate penicilli (presence of one or more branches on the stipe. The length of the metulae ranged from 12 to $15 \mu \mathrm{m}$, while that of the tightly packed phialides was 8 to $11 \mu \mathrm{m}$, Phialide were flask-shaped and more elongated. The morphological changes in P. expansum treated with Ag-Chit-NCs were investigated by HR-SEM, and alterations in conidiophores, metulae, phialides, and mature conidia characteristics were observed. Substantial morphological changes in the cell wall surface of the fungal mats were observed and conidiophore improvement was abnormal, where mycelia and conidiophores were shriveled compared to the untreated controls. The cell walls became thinner, shriveled, crinkled, and showed a decreased cytoplasmic content and modifications of the membrane integrity, and the fungal conidiophore started to shed its spores. Additionally, SEM offered evidence of the morphological changes due to exposure to Ag-Chit NCs, which included irregular branching (Figure 10b,c), loss of linearity and warty surfaces (Figure 10c,f,h), collapsed cell, the formation of a layer of extruded material (Figure 10g,h,i), a little vesicle (Figure 10i), hyphal cell wall, and damaged vesicles (Figure 10c-i).

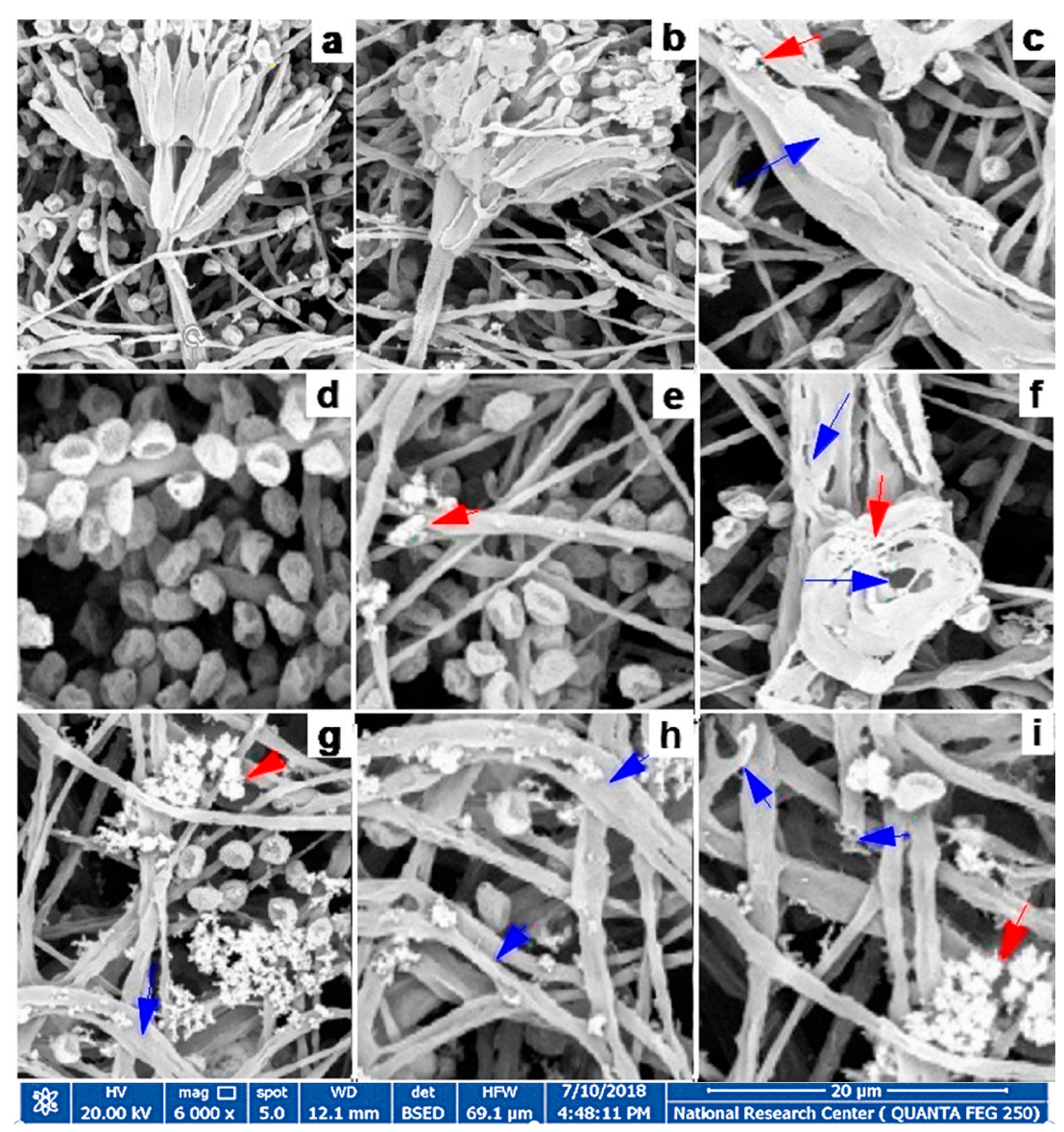

Figure 10. Scanning electron microscope (SEM) photographs of P. expansum after treatment with Ag-Chit-NCs (a) P. expansum have globose smooth-walled and ellipsoidal conidia and are from 3 to $3.5 \mu \mathrm{m}$ long (d). Red arrows refer to Ag-Chit NCs' upper different fungal structures while blue arrows refer to the morphological changes in the fungal hyphae, such as irregular branching $(\mathbf{b}, \mathbf{c})$, loss of linearity and warty surfaces $(\mathbf{c}, \mathbf{f}, \mathbf{h})$, collapsed cell, formation of a layer of extruded material $(\mathbf{g}, \mathbf{h}, \mathbf{i})$, a small vesicle (i), SEM were the markedly shriveled, crinkled cell walls, and flattened hyphae of the fungi (g-i), hyphal cell wall, and vesicle damage (c-i). 


\section{Discussion}

The present research aimed to evaluate the fungicide effect of Ag-Chit-NCs on P. expansum, which potentially has a toxic effect on animal feed. In this study, the qualitative production of patulin and citrinin was examined using HPLC. All tested P. expansum isolates were bitoxic and their ability to produce patulin toxin was very high. Of the 51 isolates tested, $33(65 \%)$ produced patulin and only one ( $2 \%$ ) citrinin [45]. In a Spanish study, three out of five P. expansum strains $(60 \%)$ produced patulin and five out of eight P. expansum strains (63\%) produced citrinin [46]. A Slovak study reported the possibility of in vitro patulin production in $37(82 \%)$ of 45 P. expansum isolates, and 22 isolates (49\%) capable of producing citrinin [47]. Most of the isolates of P. expansum (21/23, 91\%), when tested for toxigenicity, were bi-toxigenic, producing citrinin and a very high amount of patulin [48]. Four mycotoxins, including patulin (PAT), mycophenolic acid (MPA), cyclopiazonic acid (CPA), and Roquefortin C (ROC), are found in fresh ingredients, contrary to the penicillium toxin formation, which only occurs during storage. Toxins produced from Penicillium species are reported in corn silage and are associated with health problems in cattle [2]. The current study provides new information about the potential risks of patulin and citrinin in the silage of corn and other feeds.

However, the precise mechanism of Ag-Chit-NCs through which the reaction takes place is still largely unknown. Numerous reports have investigated the electrostatic attraction between the cell membranes of negatively charged microorganisms, such as bacteria, viruses, and fungi, and positively charged nanoparticles, which is very important for the antibacterial regime of these particles [49]. It has been suggested that silver nanoparticles with large surface positions can easily produce $\mathrm{Ag}^{+}$by binding to the sulfhydral $(-\mathrm{SH})$ practical groups of proteins and consequently denaturing proteins $[50,51]$. Silver nanoparticles can also cause denaturation and destruction of proton pumps by binding to fungal surface proteins, increasing the membrane permeability, or lipid bilayer proteins, which ultimately leads to the disruption of cell membranes [52,53]. Proteomic analysis in P. expansum was assayed by two-dimensional electrophoresis (2-DE) after chitosan treatment. Proteins related to DNA or protein biosynthesis, and carbohydrate metabolism were reduced, while proteins involved in antibiotics resistance and defense response were improved after chitosan treatment, which can explain the antifungal activity of chitosan against P. expansum [54].

Based on the previous research [55], it is probable that silver nanoparticles can damage the transportation system, causing outflow intracellular ions and silver ions to accumulate and inhibit processes, such as metabolism and respiration. Ag NPs also engage with protein thiol groups, which are important for the ability of microbial respiration [56]. Ag NPs can also interact with phosphorus-containing compounds, such as DNA; interfere with the replication process; or preferably attack the respiratory chain. It has also been speculated that bacterial cells associated with silver nanoparticles can absorb silver ions, which can facilitate the generation of reactive oxygen species and consequently cause necrobiosis [57]. Silver nanoparticles can also cause DNA damage, and damage the ability of replication, cell walls, cell walls, mitochondria, chromatin, and ribosomes [53]. Chitosan can penetrate the fungal cell membrane and bind to its DNA, which can inhibit mRNA synthesis and thereby interfere with the accumulation of proteins and essential enzymes [58]. The fungicide activity of chitosan against some plant pathogenic fungi, such as P. expansum and A. alternata, may be caused by membrane damage due to interactions between protonated amino groups and negatively charged cell surface proteins [21,59]. Reactive oxygen species (ROS) molecules (hydrogen peroxide, hydroxyl radicals, and peroxide) play a critical role in biological systems, and the multiplied content of intracellular ROS molecules destroys cellular components, such as DNA, RNA, proteins, and lipids, and even damages the integrity of toxic oxygen toxins. The cytotoxic effect of Ag-Chit-NC is the result of active physicochemical interactions of silver atoms with intracellular protein functional groups in addition to nitrogen and phosphate groups in the DNA molecule (Figure 11). 
A
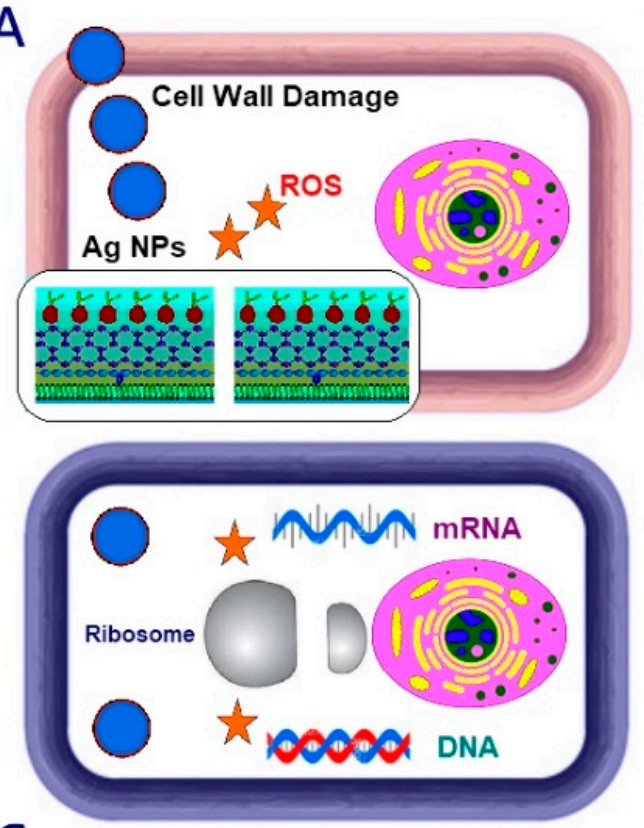

C
B

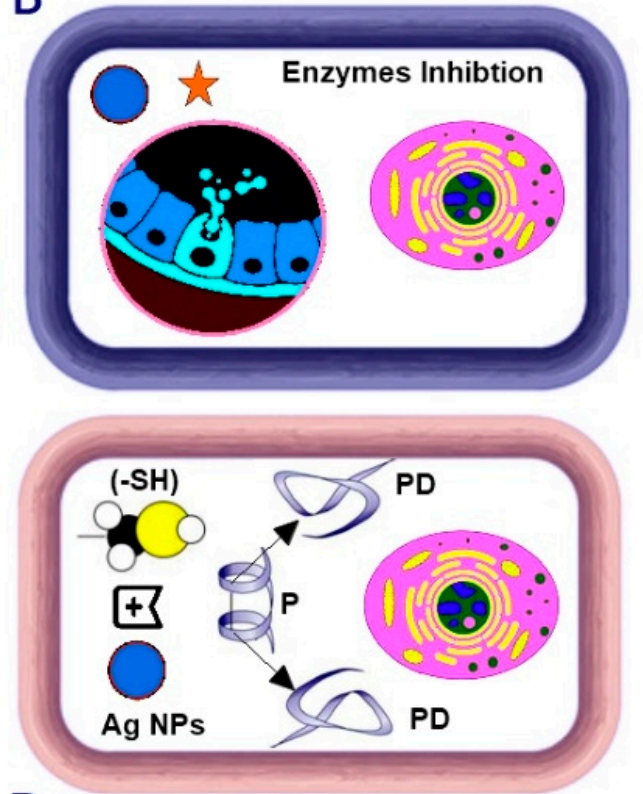

D

Figure 11. The mechanistic approach of the antifungal action indicating ROS generation induced by Ag-Chit-NCs (star). Degradation and leakage of cell walls and cell membranes, electronic transport chain disturbances, enzyme inhibition, decomposition or destabilization of ribosomes, DNA and mRNA damage, and protein denaturation.

Concerning the effects of chitosan-based nanomaterials on various fungal pathogens, the undoubted interactions between chitosan NP molecules and the polyanionic structure of microbial cell membranes cause destabilization of the cell membranes. This results in the leakage of intracellular content and then the death of the pathogen. Impaired protein synthesis and membrane destabilization are most likely the primary and secondary modes of chitosan antimicrobial activity [60]. Additionally, the mechanism of nano-chitosan includes the penetration of low-molecular-weight chitosan into the cellular DNA binding site, which further inhibits the synthesis of RNA and protein, as shown by Mostafa et al. [61]. It is believed that the current type of nanocomposite motion may be far more complicated than assumed above; such studies must clarify the proper mechanism.

Silver nanoparticles are completely deformed hyphal mats and lysed into small and elastic fragments. The remaining mycelium appears as collapsed particles that are fused with the internal components of the cell that are released. The results obtained are consistent with those found in other studies [62]. Nano-chitosan causes fungal mat accumulation, and structural changes, such as excessive branching, cell wall swelling, and reduced hyphal size, which have been observed in P. expansum and Rhizopus stolonifera [63].

\section{Conclusions}

The current study provides new information linked to the potential risks of patulin and citrinin in corn silage and confirms that mycotoxins and P. expansum can pose risks to human and animal health. The obtained results highlight the importance of being able to control the occurrence of P. expansum in dairy cattle feed. These results indicate that silver nanoparticles/chitosan nanocomposites can be further investigated as effective fungicides for applications in agriculture and food safety. Ag-Chit-NCs are a feasible and effective supplement for reducing mycotoxins in animal feed. The use of developed nanocomposites can be recommended, e.g., because disinfectant spray can be a successful chance to prevent food and feed contamination caused by mycotoxin-producing fungi. Ag-Chit-NCs are an active biopesticide that represent a new level of inexpensive biological control system that can be 
used in crops. There is a lack of clear conclusions about the chitosan-based NCs mode of action, cell membrane damage, DNA transformation, ROS production, or other mechanisms. Therefore, more studies are needed to find the right mechanism. More large-scale studies are needed. These results support the consideration of the possibility of mycotoxins occurring in dairy cows, such as patulin and citrinin. We recommend routine monitoring of animal feed colonization by other toxigenic fungi before and during harvest and identification of relevant mycotoxins. The use of silver nanoparticles/chitosan nanocomposites must also be monitored closely for side effects and examined on a case-by-case basis, especially for agricultural commodities.

Author Contributions: Conceptualization, K.A.A.-E. and E.S.-G.; Methodology, E.S.-G, A.V.N., E.V.S., K.A.A.-E., A.S. and M.A.A.; Writing-Review and editing, K.A.A.-E., M.A.A., E.S.-G., A.V.N., and E.V.S.; project administration, K.A.A.-E. All authors have read and agreed to the published version of the manuscript.

Funding: Current research was supported by the Science and Technology Development Fund (STDF), Joint Egypt (STDF)-South Africa (NRF) Scientific Cooperation, Grant ID. 27837 to Kamel Abd-Elsalam.

Acknowledgments: The authors thank S. Abramchuk for TEM- and V. Talanova for RFA measuring. Institute of Organoelement Compounds of the Russian Academy of Sciences (INEOS RAS) in part of Ag-chitosan nanocomposites synthesis in $\mathrm{SC} \mathrm{CO}_{2}$ and within the State assignment FSRC «Crystallography and Photonics» RAS in part of SAXS study.

Conflicts of Interest: The authors declare no conflict of interest. The funders had a main role in the design of the study; in the collection, analyses, or interpretation of data; in the writing of the manuscript, or in the decision to publish the results.

\section{References}

1. Raper, K.B.; Thom, C. A Manual of the Penicillia; Williams and Wilkins: Baltimore, MA, USA, 1949.

2. Mansfield, M.A.; Jones, A.D.; Kuldau, G.A. Contamination of fresh and ensiled maize by multiple Penicillium mycotoxins. Phytopathology 2008, 98, 330-336. [CrossRef] [PubMed]

3. Tangni, E.K.; Wambacq, E.; Bastiaanse, H.; Haesaert, G.; Pussemier, L.; De Poorter, J.; Foucart, G.; Van Hove, F. Survey of fungal diversity in silages supplied to dairy cattle in Belgium over a two-year period. J. Anim. Sci. Adv. 2017, 7, 1861-1873.

4. Pleadin, J.; Frece, J.; Markov, K. Mycotoxins in food and feed. Adv. Food Nutr. Res. 2019, 89, 297-345.

5. Greco, M.; Pardo, A.; Pose, G. Mycotoxigenic fungi and natural co-occurrence of mycotoxins in rainbow trout (Oncorhynchus mykiss) feeds. Toxins 2015, 7, 4594-4609. [CrossRef] [PubMed]

6. Gupta, N.; Upadhyaya, C.P.; Singh, A.; Abd-Elsalam, K.A.; Prasad, R. Applications of silver nanoparticles in plant protection. In Nanobiotechnology Applications in Plant Protection; Springer International Publishing: Berlin, Germany, 2018; pp. 247-265.

7. Abd-Elsalam, K.A.; Hashim, A.; Alghuthaymi, M.A.; Bahkali, A.H. Nanobiotechnological strategies for molud and mycotoxin control. In Nanotechnology in Food Industry, Volume VI: Food Preservation; Grumezescu, A.M., Ed.; ELSEVIER: Amsterdam, The Netherlands, 2016; pp. 337-364.

8. Abd-Elsalam, K.A.; Prasad, R. Nanobiotechnology Applications in Plant Protection; Springer: Berlin, Germany, 2018. Available online: https://www.springer.com/gp/book/9783319911601 (accessed on 19 April 2020).

9. Petica, A.; Gavriliu, S.; Lungu, M.; Buruntea, N.; Panzaru, C. Colloidal silver solutions with antimicrobial properties. Mater. Sci. Eng. B. 2008, 152, 22-27. [CrossRef]

10. Egger, S.; Lehmann, R.P.; Height, M.J.; Loessner, M.J.; Schuppler, M. Antimicrobial properties of a novel silver-silica nanocomposite material. Appl. Environ. Microbiol. 2009, 75, 2973-2976. [CrossRef]

11. Kasprowicz, M.J.; Kozioł, M.; Gorczyca, A. The effect of silver nanoparticles on phytopathogenic spores of Fusarium culmorum. Can. J. Microbiol. 2010, 56, 247-253. [CrossRef]

12. Kasprowicz, M.J.; Gorczyca, A.; Frandsen, R.J.N. The effect of nanosilver on pigments production by Fusarium culmorum (WG Sm.) Sacc. Polish, J. Microbiol. 2013, 62, 365-372. [CrossRef]

13. Jeong, S.H.; Hwnag, Y.H.; Yi, S.C. Antibacterial properties of padded PP/PE nonwovens incorporating nano-sized silver colloids. J. Mater. Sci. 2005, 40, 5413-5418. [CrossRef]

14. Korbekandi, H.; Asghari, G.; Jalayer, S.S.; Jalayer, M.S.; Bandegani, M. Nanosilver particles production using Juglans regia (L. walnut) leaf extract. J. Nat. Pharm. Prod. 2013, 8, 20-26. 
15. Pulit, J.; Banach, M.; Szczygłowska, R.; Bryk, M. Nanosilver against fungi: Silver nanoparticles as an effective biocidal factor. Acta Biochem. Pol. 2013, 60, 795-798. [CrossRef]

16. Kaur, P.; Thakur, R.; Choudhary, A. An in vitro study of the antifungal growth of silver/chitosan nanoformulations against important seed borne pathogens. Int. J. Sci. Technol. Res. 2012, 1, 83-86.

17. Mathew, T.; Kuriakose, S. Photochemical and antimicrobial properties of silver nanoparticle-encapsulated chitosan functionalized with photoactive groups. Mater. Sci. Eng. C. 2013, 33, 4409-4415. [CrossRef] [PubMed]

18. Chowdappa, P.; Shivakumar, C.; Chethana, S.; Madhura, S. Antifungal activity of chitosan-silver nanoparticles composite against Colletotrichum gloeosporioides associated with mango anthracnose. Afr. J. Microbiol. Res. 2014, 81, 1803-1812.

19. Ismaiel, A.A.; Tharwat, N.A. Antifungal activity of silver ion on ultrastructure and production of aflatoxin B1 and patulin by two mycotoxigenic strains, Aspergillus flavus OC1 and Penicillium vulpinum CM1. J. Med. Mycol. 2014, 24, 193-204. [CrossRef]

20. Rai, M.; Abd-Elsalam, K.A. Nanomycotoxicology Treating Mycotoxins in Nano Way, 1st ed.; Academic Press: Amsterdam, The Netherlands, 2019; p. 450. Available online: https://www.elsevier.com/books/ nanomycotoxicology/rai/978-0-12-817998-7 (accessed on 19 April 2020).

21. Jung, J.; Kasi, G.; Seo, J. Development of functional antimicrobial papers using chitosan/starch-silver nanoparticles. Int. J. Biol. Macromol. 2018, 112, 530-536. [CrossRef] [PubMed]

22. Said-Galiev, E.E.; Vasil'kov, A.Y.; Nikolaev, A.Y.; Lisitsyn, A.I.; Naumkin, A.V.; Volkov, I.O.; Abramchuk, S.S.; Lependina, O.L.; Khokhlov, A.R.; Shtykova, E.V.; et al. Structure of mono-and bimetallic heterogeneous catalysts based on noble metals obtained by means of fluid technology and metal-vapor synthesis. Russ. J. Phys. Chem. A 2012, 86, 1602-1608. [CrossRef]

23. Svergun, D.I. Determination of the regnlarization parameter in indirect-transform methods using perceptual criteria. J. Appl. Cryst. 1992, 25, 95-503. [CrossRef]

24. Said-Galiev, E.E.; Gamzazade, A.I.; Grigor'ev, T.E.; Khokhlov, A.R.; Bakuleva, N.P.; Lyutova, I.G.; Shtykova, E.V.; Dembo, K.A.; Volkov, V.V. Synthesis of Ag and Cu-chitosan metal-polymer nanocomposites in supercritical carbon dioxide medium and study of their structure and antimicrobial activity. Nanotechnol. Russ. 2011, 6, 341-352. [CrossRef]

25. Visagie, C.M.; Houbraken, J.; Frisvad, J.C.; Hong, S.B.; Klaassen, C.H.W.; Perrone, G.; Seifert, K.A.; Varga, J.; Yaguchi, T.; Samson, R.A. Identification and nomenclature of the genus Penicillium. Stud. Mycol. 2014, 78, 343-371. [CrossRef] [PubMed]

26. Christian, G. HPLC Tips and Tricks; Great Britain at the Iden Press: Oxford, UK, 1990; p. 608.

27. Franco, C.M.; Fente, C.A.; Vazquez, B.; Cepada, A.; Lallaoui, L.; Prognon, P.; Mahuzier, G. Simple and sensitive high-performance liquid chromatography-fluorescence method for the determination of citrinin. J. Chromatogr. 1996, 723, 69-75. [CrossRef]

28. Rubina, M.S.; Vasil'kov, A.Y.; Naumkin, A.V.; Shtykova, E.V.; Abramchuk, S.S.; Alghuthaymi, M.A.; Abd-Elsalam, K.A. Synthesis and characterization of chitosan-copper nanocomposites and their fungicidal activity against two sclerotia-forming plant pathogenic fungi. J. Nanostruct. Chem. 2017, 7, 249-258. [CrossRef]

29. Laemmli, U.K. Cleavage of structural proteins during the assembly of the head of bacteriophage T4. Nature 1970, 227, 680-685. [CrossRef]

30. Rabilloud, T.; Vuillard, L.; Gilly, C.; Lawrence, J.J. Silver-staining of proteins in polyacrylamide gels: A general overview. Cell. Mol. Biol. 1994, 40, 57-75. [PubMed]

31. Moslem, M.; Abd-Elsalam, K.; Yassin, M.; Bahkali, A. First morphomolecular identification of Penicillium griseofulvum and Penicillium aurantiogriseum toxicogenic isolates associated with blue mold on apple. Foodborne Pathog. Dis. 2010, 7, 857-861. [CrossRef] [PubMed]

32. Wagner, C.D. Faraday Discuss. Chem. Soc. 1975, 60, 291-300.

33. Fuggle, J.C.; Kallne, E.; Watso, L.M.; Fabian, D.J. Electronic structure of aluminum and aluminum-noble-metal alloys studied by soft-X-ray and X-ray photoelectron spectroscopies. Phys. Rev. B. 1977, 16, 750-761. [CrossRef]

34. Gaarenstroom, S.W.; Winograd, N. Initial and final state effects in the ESCA spectra of cadmium and silver oxides. J. Chem. Phys. 1977, 67, 3500-3506. [CrossRef] 
35. Tjeng, L.H.; Meinders, M.B.J.; van Elp, J.; Ghijsen, J.; Sawatzky, G.A.; Johnson, R.L. Electronic Structure of $\mathrm{Ag}_{2}$ O. Phys. Rev. B. 1990, 41, 3190-3199. [CrossRef]

36. Kaushik, V.K. XPS core-level spectra and Auger parameters for some silver compounds. J. Electron. Spectrosc. Relat. Phenom. 1991, 56, 273-277. [CrossRef]

37. Hoflund, G.B.; Weaver, J.F.; Epling, W.S. Ag2O XPS spectra. Surf. Sci Spectra 1994, 3, 157-162. [CrossRef]

38. Moulder, J.F.; Stickle, W.F.; Sobol, P.E.; Bomben, K.D. Handbook of X-ray Photoelectron Spectroscopy; Perkin Elmer Corporation: Eden Prairie, MN, USA, 1995.

39. Naumkin, A.V.; Kraut-Vass, A.; Gaarenstroom, S.W.; Powell, C.J. NIST X-ray Photoelectron Spectroscopy Database; Version 4.1; National Institute of Standards and Technology: Gaithersburg, MD, USA, 2012. Available online: http://srdata.nist.gov/xps/ (accessed on 19 April 2020).

40. Seah, M.P. AES: Energy calibration of electron spectrometers, IV? A re-evaluation of the reference energies. J. Electron. Spectrosc. Relat. Phenom. 1998, 97, 235-241. [CrossRef]

41. Waterhouse, G.I.N.; Bowmaker, G.A.; Metson, J.B. Oxidation of a polycrystalline silver foil by reaction with ozone. Appl. Surf. Sci. 2001, 183, 191-204. [CrossRef]

42. Powell, C.J. Recommended Auger parameters for 42 elemental solids. J. Electron. Spectrosc. Relat. Phenom. 2012, 185, 1-3. [CrossRef]

43. Samoilova, N.; Krayukhina, M.; Naumkin, A.; Yamskov, I. Eco-friendly preparation of a magnetic catalyst for glucose oxidation combining the properties of nanometal particles and specific enzyme. Monatsh. Chem. 2018, 149, 1179-1188. [CrossRef]

44. Schön, G.; Tummavuori, J.; Lindström, B.; Enzell, C.R.; Enzell, C.R.; Swahn, C.-G. ESCA Studies of Ag, Ag2O and AgO. Acta Chem. Scand. 1973, 27, 2623-2633. [CrossRef]

45. Abrunhosa, L.; Paterson, R.R.M.; Kozakiewicz, Z.; Lima, N.; Venancio, A. Mycotoxin production from fungi isolated from grapes. Lett. Appl. Microbiol. 2001, 32, 240-242. [CrossRef]

46. Bragulat, M.R.; Abarca, M.L.; Cabañes, F.J. Low occurrence of patulin- and citrinin-producing species isolated from grapes. Lett. Appl. Microbiol. 2008, 47, 286-289. [CrossRef]

47. Tancinova, D.; Felsöciova, S.; Rybarik, L.; Maskova, Z.; Cisarova, M. Colonization of grapes berries and cider by potential producers of patulin. Potravinarstvo Slovak J. Food Sci. 2015, 9, 138-142.

48. Ostry, V.; Malir, F.; Cumova, M.; Kyrova, V.; Toman, J.; Grosse, Y.; Pospichalova, M.; Ruprich, J. Investigation of patulin and citrinin in grape must and wine from grapes naturally contaminated by strains of Penicillium expansum. Food Chem. Toxicol. 2018, 118, 805-811. [CrossRef]

49. Kim, J.S.; Kuk, E.; Yu, K.N.; Kim, J.H.; Park, S.J.; Lee, H.J.; Kim, S.H.; Park, Y.K.; Park, Y.H.; Hwang, C.Y.; et al. Antimicrobial effects of silver nanoparticles. Nanomed. Nanotechnol. Biol. Med. 2007, 3, 95-101. [CrossRef] [PubMed]

50. Dibrov, P.; Dzioba, J.; Gosink, K.K.; Hase, C.C. Chemiosmotic mechanism of antimicrobial activity of Ag(p) in Vibrio cholerae. Antimicrob. Agents Chemother 2002, 46, 2668-26670. [CrossRef] [PubMed]

51. Raffi, M.; Hussain, F.; Bhatti, T.M.; Akhter, J.I.; Hameed, A.; Hasan, M.M. Antibacterial characterization of silver nanoparticles against E. coli ATCC-15224. J. Mater. Sci. Technol. 2008, 24, 192-196.

52. Kim, J.; Lee, J.; Kwon, S.; Jeong, S. Preparation of biodegradable polymer/silver nanoparticles composite and its antibacterial efficacy. J. Nanosci. Nanotechnol. 2009, 9, 1098-1102. [CrossRef] [PubMed]

53. Li, M.; Chen, C.; Xia, X.; Garba, B.; Shang, L.; Wang, Y. Proteomic analysis of the inhibitory effect of chitosan on Penicillium expansum. Food Sci. Technol. 2019. [CrossRef]

54. Xia, Z.K.; Ma, Q.H.; Li, S.Y.; Zhang, D.Q.; Cong, L.; Tian, Y.L.; Yang, R.Y. The antifungal effect of silver nanoparticles on Trichosporon asahii. J. Microbiol.; Immunol. Infect. 2016, 49, 182-188. [CrossRef]

55. Du, H.; Lo, T.M.; Sitompul, J.; Chang, M.W. Systems-level analysis of Escherichia coli response to silver nanoparticles: The roles of anaerobic respiration in microbial resistance. Biochem. Biophys. Res. Commun. 2012, 424, 657-662. [CrossRef]

56. Arokiyaraj, S.; Choi, S.H.; Lee, Y.; Bharanidharan, R.; Hairul-Islam, V.I.; Vijayakumar, B.; Oh, Y.K.; Dinesh-Kumar, V.; Vincent, S.; Kim, K.H. Characterization of ambrette seed oil and its mode of action in bacteria. Molecules 2015, 20, 384-395. [CrossRef]

57. Carlson, C.; Hussain, S.M.; Schrand, A.M.; K. Braydich-Stolle, L.; Hess, K.L.; Jones, R.L.; Schlager, J.J. Unique cellular interaction of silver nanoparticles: Size-dependent generation of reactive oxygen species. J. Phys. Chem. B. 2008, 112, 13608-13619. [CrossRef] 
58. Calvo, P.; Remunan-Lopez, C.; Vila-Jato, J.L.; Alonso, M.J. Novel hydrophilic chitosan-polyethylene oxide nanoparticles as protein carriers. J. Appl. Polym. Sci. 1997, 63, 125-132. [CrossRef]

59. Kalagatur, N.K.; Ghosh, N.; Sivaraman, O.; Sundararaj, N. Antifungal activity of chitosan nanoparticles encapsulated with Cymbopogon martinii essential oil on plant pathogenic fungi Fusarium graminearum. Front. Pharmacol. 2018, 9, 610. [CrossRef] [PubMed]

60. Márquez, I.G.; Akuaku, J.; Cruz, I.; Cheetham, J.; Golshani, A.; Smith, M.L. Disruption of protein synthesis as antifungal mode of action by chitosan. Int. J. Food Microbiol. 2013, 164, 108-112. [CrossRef] [PubMed]

61. Mostafa, M.; Almmoamr, H.; Abd-Elsalam, K.A. Nanoantimicrobials Mechanism of Action. In Nanobiotechnology Applications in Plant Protection; Abd-Elsalam, K., Prasad, R., Eds.; Springer: Berlin/Heidelberg, Germany, 2018.

62. Abdel-Hafez, S.I.; Nafady, N.A.; Abdel-Rahim, I.R.; Shaltout, A.M.; Daròs, J.A.; Mohamed, M.A. Assessment of protein silver nanoparticles toxicity against pathogenic Alternaria solani. 3 Biotech. 2016, 6, 199. [CrossRef] [PubMed]

63. Oliveira Junior, E.N.D.; Melo, I.S.D.; Franco, T.T. Changes in hyphal morphology due to chitosan treatment in some fungal species. Brazil. Archiv. Biol. Technol. 2012, 55, 637-646. [CrossRef]

(C) 2020 by the authors. Licensee MDPI, Basel, Switzerland. This article is an open access article distributed under the terms and conditions of the Creative Commons Attribution (CC BY) license (http://creativecommons.org/licenses/by/4.0/). 